\title{
Review \\ Denitrification in Intrinsic and Specific Groundwater Vulnerability Assessment: A Review
}

\author{
Gianluigi Busico (D), Luigi Alessandrino (D) and Micòl Mastrocicco *(D) \\ Department of Environmental, Biological and Pharmaceutical Sciences and Technologies, \\ Campania University “Luigi Vanvitelli”, Via Vivaldi 43, 81100 Caserta, Italy; \\ gianluigi.busico@unicampania.it (G.B.); luigi.alessandrino@unicampania.it (L.A.) \\ * Correspondence: micol.mastrocicco@unicampania.it
}

check for updates

Citation: Busico, G.; Alessandrino, L.; Mastrocicco, M. Denitrification in Intrinsic and Specific Groundwater Vulnerability Assessment: A Review. Appl. Sci. 2021, 11, 10657. https:// doi.org/10.3390/app112210657

Academic Editor: Bart Van der Bruggen

Received: 18 September 2021 Accepted: 10 November 2021 Published: 12 November 2021

Publisher's Note: MDPI stays neutral with regard to jurisdictional claims in published maps and institutional affiliations.

Copyright: (c) 2021 by the authors. Licensee MDPI, Basel, Switzerland. This article is an open access article distributed under the terms and conditions of the Creative Commons Attribution (CC BY) license (https:// creativecommons.org/licenses/by/ $4.0 /)$.

\begin{abstract}
Several groundwater vulnerability methodologies have been implemented throughout the years to face the increasing worldwide groundwater pollution, ranging from simple rating methodologies to complex numerical, statistical, and hybrid methods. Most of these methods have been used to evaluate groundwater vulnerability to nitrate, which is considered the major groundwater contaminant worldwide. Together with dilution, the degradation of nitrate via denitrification has been acknowledged as a process that can reduce reactive nitrogen mass loading rates in both deep and shallow aquifers. Thus, denitrification should be included in groundwater vulnerability studies and integrated into the various methodologies. This work reviewed the way in which denitrification has been considered within the vulnerability assessment methods and how it could increase the reliability of the overall results. Rating and statistical methods often disregard or indirectly incorporate denitrification, while numerical models make use of kinetic reactions that are able to quantify the spatial and temporal variations of denitrification rates. Nevertheless, the rating methods are still the most utilized, due to their linear structures, especially in watershed studies. More efforts should be paid in future studies to implement, calibrate, and validate user-friendly vulnerability assessment methods that are able to deal with denitrification capacity and rates at large spatial and temporal scales.
\end{abstract}

Keywords: denitrification rate; aquifer; groundwater quality; vulnerability assessment; nitrate pollution; saturated and unsaturated zones

\section{Introduction}

Around the world, several water bodies do not meet the minimum quality standards necessary to ensure their utilization for anthropic activities [1-3] and groundwater quality is even declining over time [4]. This phenomenon is attributable to the presence of different pollutants in both surface and groundwater resources [5], due either to anthropogenic activities or natural processes [6]. Specifically, the subsurface pollution related to nitrogen surplus is considered a persistent and widespread issue, especially in agricultural areas [7], where the excess of nitrate $\left(\mathrm{NO}_{3}{ }^{-}\right)$represents a major concern [8-11]. $\mathrm{NO}_{3}{ }^{-}$ is simultaneously: (i) an indispensable nutrient for agricultural production, necessary to properly meet the increasing food demands for communities, and (ii) the most widespread groundwater pollutant worldwide [12], which can be linked to numerous severe human health threats [13]. Significant increases in groundwater $\mathrm{NO}_{3}{ }^{-}$pollution can be attributed to several processes such as: (i) overuse of fertilizers and/or animal waste, (ii) sewage leaks, (iii) improper management of wastewater effluents, and (iv) wastewater treatment without denitrification (DNT) [14]. Driven by this worrying scenario, the United States Environmental Protection Agency [15] and with the European Union Council [16] have established a maximum $\mathrm{NO}_{3}{ }^{-}$concentration of $50 \mathrm{mg} / \mathrm{L}$ in drinking water. The natural processes of water dilution and $\mathrm{NO}_{3}{ }^{-}$decay represent the main processes that could attenuate $\mathrm{NO}_{3}{ }^{-}$concentration in water bodies. The degradation of $\mathrm{NO}_{3}{ }^{-}$through DNT 
can reduce the reactive nitrogen $(\mathrm{Nr})$ levels in both deep and shallow aquifers $[17,18]$. The process occurs both in the saturated and unsaturated zones under mildly reducing conditions [19], with dissolved oxygen usually below $2 \mathrm{mg} / \mathrm{L}$. It generally refers to the heterotrophic DNT, operated by facultative anaerobic bacteria, using a carbon source as electron donor and $\mathrm{NO}_{3}{ }^{-}$as electron acceptor to produce atmospheric nitrous oxide $\left(\mathrm{N}_{2} \mathrm{O}\right)$ and nitric oxide $(\mathrm{NO})$, which can be further reduced to dinitrogen $\left(\mathrm{N}_{2}\right)$. Unfortunately, the DNT byproducts that are generated when DNT is incomplete are also considered greenhouse gases and ozone-depleting substances [20]. While heterotrophic DNT is the most widely known pathway to reduce $\mathrm{NO}_{3}{ }^{-}$in the subsurface, other processes can help to diminish $\mathrm{NO}_{3}{ }^{-}$concentrations, like dissimilatory $\mathrm{NO}_{3}{ }^{-}$reduction to ammonium [21]. This process is an anaerobic respiration of organic matter by chemoorganoheterotrophic microbes using $\mathrm{NO}_{3}{ }^{-}$as electron donor, but unlike DNT, it conserves bioavailable $\mathrm{Nr}$ in the system as ammonium. Other relevant processes ubiquitously occurring in subsurface environments are anammox [22] and autotrophic DNT via different inorganic electron donors [23], includign dissolved reduced species such as ferrous iron and sulfide or solid phases such as pyrrhotite and pyrite. Despite the many biogeochemical processes that can attenuate $\mathrm{NO}_{3}{ }^{-}$, fertilization often occurs at amounts exceeding both crop demand and the natural attenuation capacity of soils. This generates a $\mathrm{NO}_{3}{ }^{-}$surplus which can be readily transported by percolating waters through the soil profile and can promote $\mathrm{NO}_{3}{ }^{-}$accumulation in groundwater bodies, if oxic conditions prevail [24,25]. Moreover, a reliable identification of $\mathrm{NO}_{3}{ }^{-}$sources may be difficult due to the occurrence of multiple releasing sources and the complementarity of several geogenic and anthropogenic processes acting in the same area [26-29]. In addition, the occurrence of $\mathrm{NO}_{3}{ }^{-}$may suffer from consistent temporal variations [30], depending on: (i) the precipitation regime [31], (ii) the hydrogeological conditions [32], and (iii) the land use [33].

Several tools and techniques have been proposed to estimate groundwater pollution, ranging from analytical, graphical, and statistical methods. They have been greatly enhanced since the advent and the improvement of geographic information systems (GIS), which made the interpretation and representation of groundwater quality easier than before [34]. Among all available methodologies, groundwater vulnerability assessment tools have attracted researchers' attention due to their relatively straightforward applicability and the production of understandable results by non-specialists. The concept of aquifer vulnerability $[35,36]$ aims to quantify the susceptibility of an aquifer to be adversely affected by any pollutant load imposed on the land surface. Groundwater vulnerability cannot be directly measured and quantified in the field since it represents a qualitative classification as a function of the main hydrogeological conditions of the study area, which could vary drastically from one place to another. The vulnerability can be classified in two types: (i) intrinsic and (ii) specific vulnerability [37]. The intrinsic vulnerability only depends on hydrogeological characteristics regardless the pollutant types. The specific vulnerability instead refers to the vulnerability of a given pollutant, involving in the evaluation processes both the pollutant's physical-chemical characteristics and its mass loading rates. In recent decades, different methodologies to assess groundwater vulnerability were proposed and tested around to world. They can be distinguished in four main categories: (i) deterministic or simulation models, (ii) overlay and index techniques, (iii) statistical tools, and (iv) hybrid methodologies [38]. All methodologies offer different advantages and, at the same time, they suffer from some drawbacks. For example, both statistical and deterministic models ask for a high-quality dataset and a massive quantity of information, especially for calibration and validation procedures, while overlay and indices methodologies could be affected by subjectivities in rates classification and weights assignment. Weighting and rating indices are easy-to-use methodologies, need relatively low amounts of data, are usually applicable to large domains, and can be easily modified and updated. On the other hand, they produce static snapshots of the aquifer vulnerability, which can be only used as a screening tool for regional and national scale management or planning. Conversely, process-based methods can produce a transient representation of groundwater quality, but 
they are mostly used on small domains (e.g., field or site scales) due to computational burdens and the requirement of high-quality and -frequency data.

In general, the groundwater pollution status is controlled by a wide range of physical and biogeochemical processes (e.g., dilution, sorption, and degradation), which contribute to decreasing pollutants concentrations. As a result, $\mathrm{N}$ loads of rivers and aquifer systems often reflect only a minor part of the $\mathrm{N}$ surplus within the corresponding river basin area due to decay processes during the aquifer transit and within the surface water bodies themselves [39]. Many studies have highlighted that among these decay processes, DNT has a large potential to reduce the relative vulnerability of water bodies [40,41]. Unfortunately, these attenuation processes are not always properly incorporated within the vulnerability assessment methodologies [42,43], but only considered indirectly in lumped parameters.

This paper deals with the last 20 years of literature on groundwater vulnerability and, specifically, it focuses on the introduction of $\mathrm{NO}_{3}{ }^{-}$attenuation processes within the evaluation assessment. The main difficulties in including, directly or indirectly, the DNT process in some methodologies, the improvements in results, and the effects on the consequent water management strategies are also discussed. With this review, we sought to highlight the main limitations and research gaps incurred in the past studies, delineating the future research needs aimed to obtain a reliable evaluation of groundwater intrinsic and specific vulnerability to $\mathrm{NO}_{3}{ }^{-}$, explicitly including DNT rates for both the saturated and unsaturated zones.

\section{Denitrification in the Unsaturated and Saturated Zones}

$\mathrm{NO}_{3}{ }^{-}$attenuation is controlled by several physical and biogeochemical processes occurring in the saturated and unsaturated zones. The understanding and quantification of these processes are mandatory to protect groundwater from the risk associated with point and non-point sources of $\mathrm{NO}_{3}{ }^{-}$pollution [44]. Figure 1 reports a schematic representation of the processes acting in the unsaturated and saturated zones.

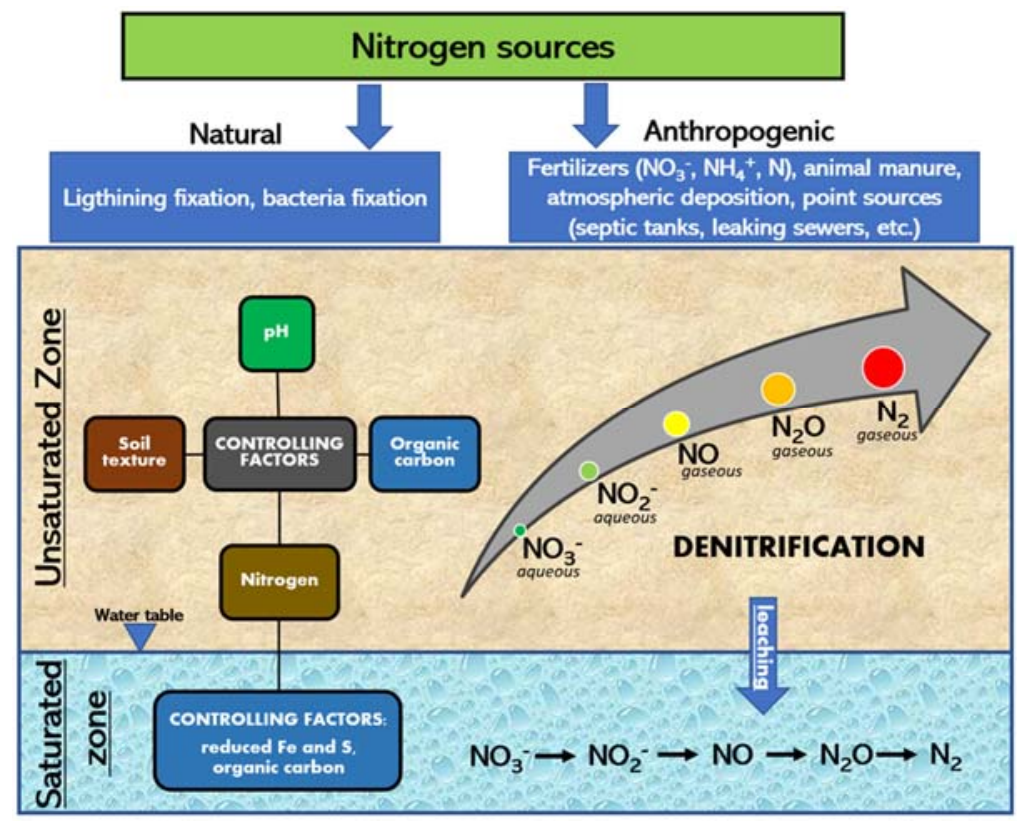

Figure 1. Conceptual model of DNT occurring in the unsaturated and saturated zones.

Among all biogeochemical processes, DNT is considered the predominant factor responsible for $\mathrm{NO}_{3}{ }^{-}$attenuation in agricultural soil [45], representing an important pathway for $\mathrm{Nr}$ losses. Nevertheless, DNT also has a serious adverse environmental effect, being the principal source of $\mathrm{N}_{2} \mathrm{O}$ and $\mathrm{NO}$, accounting for $70 \%$ of the $\mathrm{N}_{2} \mathrm{O}$ emitted annually from the biosphere into the atmosphere [46]. Several factors regulate DNT in the unsaturated and in the saturated zones; in fact, the DNT rate is a direct function of: 
(i) soil water content, (ii) hypoxic and anoxic conditions, (iii) $\mathrm{NO}_{3}{ }^{-}$concentrations, and (iv) organic carbon substrates, such as soil organic matter and crop residues [47]. Soil texture could also directly influence DNT, especially in the topsoil, via the formation of micro-niches where anoxic condition would prevail [48]. Nr mass loading rate significantly affects DNT, especially when the $\mathrm{Nr}$ supplied through fertilizer is higher than the crop $\mathrm{Nr}$ requirement $[49,50]$. Within the unsaturated profile, DNT could prevent leached $\mathrm{NO}_{3}{ }^{-}$ from reaching the water table, if labile carbon sources are also present [51,52]; in any case, DNT rates could be significantly limited by the vertical unsaturated geochemical and microbiological variability.

DNT in the saturated zone has been less extensively studied with respect to DNT in the unsaturated zone. Despite this, DNT in groundwater systems is still relevant and mainly controlled by the same conditions as for the unsaturated zone. For instance, the presence of electron donors (organic carbon, reduced iron, and/or reduced sulfur) have been identified as the most limiting factor among with anoxic conditions, more than $\mathrm{NO}_{3}{ }^{-}$ and nutrient availability [44]. The above-mentioned DNT controlling factors (Figure 1), both in the unsaturated and saturated zones, are usually considered in vulnerability assessment methodologies to indirectly account for DNT where direct measurements are not available. Furthermore, as will be further discussed in the following chapters, the main factor considered in most used methodologies (namely the rating and weights methods) is the soil texture, which is easier to measure and analyze compared to the other factors controlling DNT in the unsaturated or saturated zone.

Based on these considerations, Table 1 shows the DNT rates for the unsaturated zone, and more specifically in the topsoil, obtained from both laboratory and field studies, depending on the soil texture and for different land covers. The average DNT value for laboratory studies is $460 \mathrm{Kg}-\mathrm{N} / \mathrm{ha} /$ year, with values that can reach up to $3600 \mathrm{Kg}$ $\mathrm{N} /$ ha/year, while for field studies the average DNT rate is $60 \mathrm{Kg}-\mathrm{N} / \mathrm{ha} /$ year, with a maximum of $550 \mathrm{Kg}-\mathrm{N} / \mathrm{ha} /$ year. It is evident that under controlled laboratory conditions, the DNT rates tend to be much higher (approximately one order of magnitude) than in field conditions, where local limiting factors may act to reduce the effectiveness of DNT both spatially and seasonally. Concerning the DNT rates in the saturated zone, it must be stressed that the studies available in the literature are not numerous, especially in the field, given the greater difficulty of the monitoring techniques required and the duration of the studies to be carried out. Nevertheless, recent studies $[53,54]$ reported DNT rates up to $320-390 \mathrm{Kg}-\mathrm{N} / \mathrm{ha} /$ year, underlining the fact that the contribution of DNT processes within the saturated zone cannot be neglected in the definition of the vulnerability of a given territory.

Table 1. DNT rates for different experimental setup, land use, and texture.

\begin{tabular}{ccccc}
\hline Land Use and Location & $\begin{array}{c}\text { Rate } \\
\text { (Kg-N/ha/Year) }\end{array}$ & Type of Matrix & Reference \\
\hline Drainage Basin, California & $0-3600$ & Sand & {$[55]$} \\
Agricultural field, & $12-300$ & Organic soil & {$[56]$} \\
Georgia & $43-159$ & Clay & {$[56]$} \\
LABORATORY & Forest, Georgia & $0-2190$ & Clay Loam & {$[57]$} \\
& Grassland, Europe & $6-119$ & Silty Clay Loam & {$[58]$} \\
Rice, China & 6.2 & Silty Clay & {$[59]$} \\
& Tallgrass prairie, USA & $0.5-135$ & Various & {$[60]$} \\
\hline Wetland, China & & & \\
\hline
\end{tabular}


Table 1. Cont.

\begin{tabular}{|c|c|c|c|c|}
\hline & Land Use and Location & $\begin{array}{c}\text { Rate } \\
\text { (Kg-N/ha/Year) }\end{array}$ & Type of Matrix & Reference \\
\hline \multirow{22}{*}{ FIELD } & $\begin{array}{l}\text { Agricultural field, } \\
\text { Germany }\end{array}$ & 10-150 & Loam & {$[40]$} \\
\hline & $\begin{array}{c}\text { Grass-clover, New } \\
\text { Zealand }\end{array}$ & 3.4 & Fine Sandy Loam & {$[61]$} \\
\hline & Herbal ley, New Zealand & 4.4 & Fine Sandy Loam & [61] \\
\hline & $\begin{array}{c}\text { Fertilized grass, New } \\
\text { Zealand }\end{array}$ & 19.3 & Fine Sandy Loam & {$[61]$} \\
\hline & $\begin{array}{l}\text { Agricultural field, } \\
\text { Maryland }\end{array}$ & 0.8 & Silty loam & [62] \\
\hline & $\begin{array}{l}\text { Agricultural field, } \\
\text { England }\end{array}$ & $73-547$ & Sandy loam & [63] \\
\hline & Corn, Canada & 13.5 & Sandy loam & {$[64]$} \\
\hline & Farm, Netherlands & $56-120$ & Peat & [65] \\
\hline & Forest, Maryland & 1.5 & Silty loam & [62] \\
\hline & Forest, Globe & $0-239$ & Various & [66] \\
\hline & Forest, Swiss & $2-3$ & Clay & [67] \\
\hline & Grassland, Europe & $20-400$ & Various & [68] \\
\hline & Grassland, Maryland & 1.4 & Silty loam & [62] \\
\hline & Grassland, Spain & $3-37$ & Clay Loam & [69] \\
\hline & $\begin{array}{l}\text { Grassland, The } \\
\text { Netherlands }\end{array}$ & $100-120$ & Peat & [65] \\
\hline & Horticultural field, USA & 95-233 & Sandy loam & [70] \\
\hline & Pasture, New Zealand & $5-25$ & Silty loam & {$[71]$} \\
\hline & Ryegrass, Germany & $0.2-3.1$ & Sandy loam & [72] \\
\hline & Ryegrass, Netherlands & $3-25$ & Various & [73] \\
\hline & Ryegrass, USA & $2-110$ & Loam & [74] \\
\hline & Wheat, Canada & $3.2-22.5$ & Clay Loam & [75] \\
\hline & Wheat, USA & $0.7-1.7$ & Silty loam & [76] \\
\hline
\end{tabular}

\section{Materials and Methods}

For this review, several studies focusing on intrinsic and specific groundwater vulnerability assessments performed in the last 20 years (2000-2020) worldwide were considered. The Scopus database (Elsevier) was probed as the main worldwide peer-reviewed manuscripts archive, using specific combinations of keywords, such as: groundwater vulnerability, DNT, nitrate vulnerable zone, nitrate attenuation factors, specific and intrinsic vulnerability. Given the large number of studies and applications focusing on the groundwater vulnerability topic, only the contributions published in peer-reviewed international journals were considered. Furthermore, the use of the keyword DNT in combination with at least others two keywords was necessary to exclude all the studies not related to the chosen topic. Specifically, all the studies on standard rating methods, such as DRASTIC, GOD, or SINTACS, without a clear reference to DNT were excluded, along with process-based models not adequately adapted to vulnerability and DNT assessment purposes. Similarly, this was done for the statistical and hybrid methodologies.

This review is not meant to serve as a general review on vulnerability assessment methods, since recent complete studies are already present in the literature $[36,38,43]$, but aimed only to revise the role of DNT in groundwater vulnerability assessment studies; accordingly, only those papers where DNT was explicitly considered were retained. All the reviewed studies were divided into four main categories (Figure 2) discussed separately: (i) rating methods, (ii) numerical models, (iii) statistical methods, and (iv) hybrid methodologies. This review offers an overall explanation of how already known vulnerability methodologies incorporate the process of DNT without discussing every single application, focusing the discussion on methodologies that showed an implicit or explicit involvement of DNT in the vulnerability assessment. 


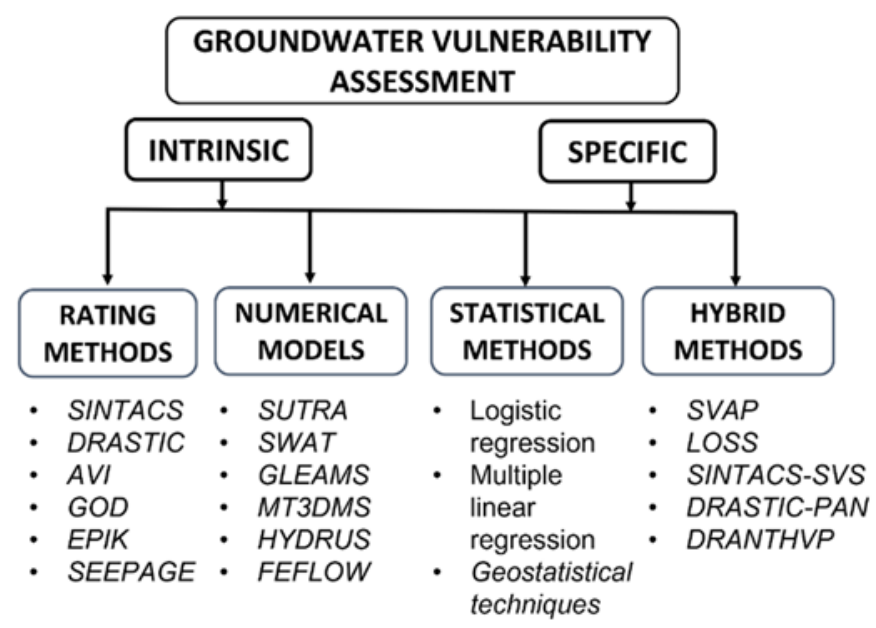

Figure 2. Conceptual organization of this review.

\section{Results and Discussion}

In this section, the main categories highlighted in Figure 2 will be discussed to assess the role of DNT in enhancing the already available intrinsic and specific groundwater vulnerability assessment methods.

\subsection{Rating Methods for Nitrate Vulnerability Assessment}

Among all methodologies to assess aquifer vulnerability, the rating methods are surely the most widely utilized [38]. The main advantage lies in their straightforward applicability and in their highly understandable results. The pioneer methods of this class are DRASTIC [77] and GOD [78], followed by many other methodologies specifically created to assess the intrinsic aquifer vulnerability, such as AVI [79], EPIK [80], SINTACS [81], SEEPAGE [82], and many more. A comprehensive review of these methodologies is available in Machiwal et al. [38]. These methods have been widely applied both on watershed, regional, and even global scales, producing reliable results [83-87]. They consist of the combination of thematic layers, representing the different physiographic attributes that control the groundwater vulnerability to pollution of a given area; the most utilized factors are: (i) depth to the water table, (ii) recharge, (iii) unsaturated and saturated media, (iv) soil texture, (v) topographic slope, (vi) hydraulic conductivity, (vii) hydraulic resistance, and (viii) presence of phreatic or confined aquifers. Each parameter is classified using a range of rates (generally 1 to 10) and multiplied for a specific weight, indicating the individual parameter importance and magnitude. These lumped parameters incorporate most physical attenuation processes (such as dilution and travel time) but disregard biogeochemical processes (such as DNT) that may occur along the pathway between the pollution sources (usually at land surface) and the considered target, namely the saturated portion of the aquifer and/or the surface water bodies towards which groundwater discharges (Figure 3).

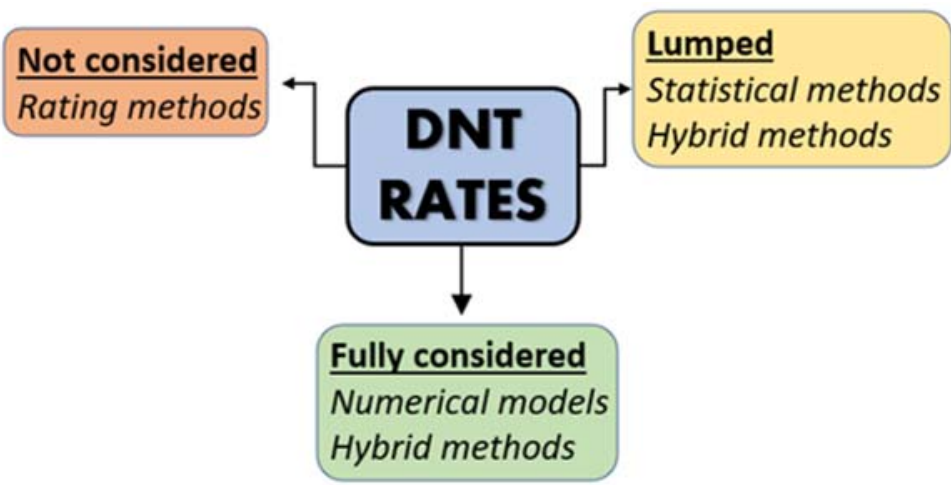

Figure 3. DNT rates as employed in the different vulnerability assessment methods. 
It should be mentioned that some biogeochemical processes are often a function of soil properties (such as texture and water content), therefore, many end users of rating methods claim that natural attenuation processes are accounted for, even though not explicitly. Specifically, soil texture could influence the redox values suitable for DNT, which were found to be more favorable in clayey textured soils than in sandy textured soils $[88,89]$. Nevertheless, other important factors influencing DNT, like organic carbon substrates and $\mathrm{Nr}$ mass loading rates, are generally completely neglected. The same assumption is made for the unsaturated and saturated zone where the pollutant attenuation can be regulated by several processes that depend on their physical and hydraulic properties (e.g., thickness, hydraulic conductivity, and presence of organic matter). Both saturated and unsaturated zones are commonly classified considering only the lithological characteristic and the thickness of the media. Moreover, all methods offer a large range of rates, especially for saturated and unsaturated media classification, implying an inherent subjectivity (expert judgment). In any case, the classification is usually made considering dispersion and diffusion capacity, neglecting the main biogeochemical factors that can occur within the saturated and unsaturated zones. The SEEPAGE methodology [82] tried to overcome this problem, introducing a potential attenuation parameter referring to the soil and subsoil characteristics. Specifically, the introduced attenuation parameters based its classification on several factors that can be easily related to DNT, such as: (i) soil surface and subsoil texture, (ii) topsoil $\mathrm{pH}$, (iii) organic matter content of topsoil, (iv) soil drainage class, and (v) soil permeability. Unfortunately, the methodology has not been so widely applied in comparison to DRASTIC and SINTACS methods and only a few applications have been documented so far $[90,91]$.

On the other hand, much more attention has been paid to the determination of the different $\mathrm{NO}_{3}{ }^{-}$sources, so much so that there are numerous studies that have correlated the rating methods to land use [92-94] and to probabilistic models [95,96].

\section{Nitrate Vulnerable Zones}

A step forward has been made with the introduction of several methodologies aimed at evaluating nitrate vulnerable zones (NVZ). Conserving the same structure of a rating method, specific parameters connected to $\mathrm{NO}_{3}{ }^{-}$leaching and attenuation were introduced in the evaluation procedure. An example is the agricultural $\mathrm{NO}_{3}{ }^{-}$hazard index named IPNOA, which was proposed by Padovani and Trevisan [97]. IPNOA facilitates the assessment of hazard factors contributing to $\mathrm{NO}_{3}{ }^{-}$load and control factors able to amplify or decrease the $\mathrm{NO}_{3}{ }^{-}$load. Specifically, the hazard factors are chosen among agricultural sources of Nr input which could have a potential impact on groundwater resources, such as: (i) applied organic fertilizers, (ii) synthetic fertilizers, and (iii) wastewaters, while the control factors used to evaluate $\mathrm{NO}_{3}{ }^{-}$behavior in site-specific conditions and farming practices are: (i) $\mathrm{Nr}$ content in soil, (ii) climate characteristic, (iii) agronomic practices, and (iv) irrigation techniques. For example, tillage operations could greatly influence DNT [98,99], as well as the soil $\mathrm{Nr}$ content and the fertilizer application rate [47]. The methodology was applied by several authors [33,100-102] and was also coupled with classical rating methods, such as SINTACS, with the aim of improving $\mathrm{NO}_{3}{ }^{-}$vulnerability assessment $[103,104]$. Another approach for NVZ delineation is the calculation of N budgets and surpluses on the farmland scale [105], watershed scale [106-110], or even at the subcontinental scale [111-113]. It consists of differentiating between the soil $\mathrm{Nr}$ inputs and outputs, where inputs usually are: (i) synthetic fertilizers, (ii) sewage sludge and animal manure, (iii) biological $\mathrm{N}$ fixation, and iv) atmospheric deposition, while the outputs are: (i) the amount of crop harvested and removed from the field, (ii) crop residues, (iii) leached $\mathrm{Nr}$, and (iv) degassed $\mathrm{N}$. This methodology offers a mappable output of the available Nr content for leaching. Rebolledo et al. [114] presented an overlay index method for NVZ identification through the analysis of three groups of factors: the first was related to intrinsic vulnerability (water table, saturated hydraulic conductivity, and aquifer type), the second considered the attenuation factors acting in the soil and specifically related 
to DNT capacity (organic carbon, $\mathrm{pH}$, and texture), and the third indicated the pollutant infiltration capacity (slope, precipitation, and evapotranspiration). Rates and weights were then assigned using Pearson's r correlation and analytical hierarchical process (AHP) to limit subjectivity. Arauzo et al. [115] combined the N-surplus approach with a rating methodology specially developed for NVZ. Similarly, Cameira et al. [116] developed a global risk index (GRI), integrating the $\mathrm{N}$ budget with water surplus (irrigation and rain), soil permeability, unsaturated zone residence time, and surface morphology. In these methodologies, DNT is related to different parameters such as soil texture, soil $\mathrm{pH}, \mathrm{Nr}$ input, and unsaturated zone residence time. Indeed, DNT is more likely to occur when the travel time through the unsaturated zone is long [44]. Following the same concept, Busico et al. [117] proposed a rating methodology for NVZ using all those parameters directly connected to $\mathrm{NO}_{3}{ }^{-}$concentration in groundwater, combining the classical parameters of the unsaturated zone media, surface morphology, and recharge with the natural soil $\mathrm{Nr}$ content and the amount of fertilizers recommended for different kind of crops. The methodologies described so far have been applied in several case studies and compared to canonical vulnerability assessment methods and were found to deliver more realistic results [117-119].

\subsection{Statistical Methods}

The statistical methodologies aim to assess groundwater vulnerability to $\mathrm{NO}_{3}{ }^{-}$mapping pollution probabilities at a specific site. The computation is based on the correlations between some parameters describing the aquifer properties and the sources and occurrences of pollutants, such as: (i) aquifer type (lithology or confinement condition), (ii) $\mathrm{Nr}$ mass loading rates, (iii) water physical-chemical variables (major ions, trace elements, and isotopic composition), and (iv) soil characteristics (texture, organic carbon, and $\mathrm{pH}$ ). To fulfill this purpose, these methodologies require extensive datasets on both physiographic and geochemical properties of the study area. They may incorporate a wide range of inputs related to both the anthropogenic stresses and the natural conditions of the groundwater system [120]. Among the various statistical tools, the most utilized for aquifer vulnerability assessment to $\mathrm{NO}_{3}{ }^{-}$are: (i) logistic regression [121], (ii) multiple linear regression [122], and (iii) geostatistical techniques [123]. Logistic regression allows for the evaluation of those natural and anthropogenic factors that could impact the probability that $\mathrm{NO}_{3}{ }^{-}$concentrations will exceed a specified threshold. Commonly, statistical methods involve numerous factors related to the attenuation processes and to DNT, like soil characteristics and Nr loads [124-129]. Moreover, some authors identified the anoxic condition as the main attenuation factor [126,130-132]. Boy-Roura et al. [133] built a multiple linear regression model using five main variables, one of which was identified as indicator of DNT occurrence. The variable was assessed using $\mathrm{N}$-stable isotopes in $\mathrm{NO}_{3}{ }^{-}$ and dissolved oxygen.

\subsection{Numerical Models}

With respect to the qualitative methods (rating methods), the numerically and physically based methods for the assessment of aquifer vulnerability to $\mathrm{NO}_{3}{ }^{-}$involve the analysis of all the relevant processes occurring within the unsaturated and the saturated systems. Numerical models subdivide the tridimensional domain into cells or elements (depending on the method used) where the flow, dispersive transport, and reactions among each cell are computed by differential equations of flux and mass conservation solved iteratively, starting from user-defined initial and boundary conditions. Thus, with numerical methods, an accurate temporal and spatial evolution of the fate and transport of $\mathrm{NO}_{3}{ }^{-}$in the subsurface can be achieved. In fact, these methodologies aim to determine the specific vulnerability for diffuse pollution sources rather than the intrinsic vulnerability of an aquifer, emphasizing the physical, chemical, and biological processes controlling the fate and transport of contaminants in both the unsaturated and saturated zones. Moreover, process-based models also provide the temporal variation of vulnerabil- 
ity, a concept often neglected by other methods. Among all the numerical models, the most used are: GLEAMS [134], SUTRA [135], MODFLOW [136] coupled with MT3DMS [137], FEFLOW [138], PHT3D [139], HYDRUS [140,141], and SWAT [142]. All of these models explicitly involve $\mathrm{Nr}$ attenuation processes, such as DNT, in their modules. For example, the $\mathrm{N}$ module of SWAT intrinsically considers various $\mathrm{NO}_{3}{ }^{-}$reduction processes, such as mineralization, volatilization, and DNT, which is simulated in the soil layer as a function of the amount of $\mathrm{NO}_{3}{ }^{-}$, organic carbon, and temperature. The sink and source package of MT3DMS was designed to simulate chemical processes, such as $\mathrm{NO}_{3}{ }^{-}$decay, following a first-order degradation reaction or fully integrating the reaction stoichiometries of the main terminal electron acceptors processes [143]. GLEAMS incorporates a $\mathrm{N}$ cycling algorithm, which considers $\mathrm{N}$ plant uptake and fixation among with fertilizers and manure applications. Due to their high versatility, despite these models are recognized as valuable tools for groundwater vulnerability assessment, they find application in a large variety of settings, such as: pollution transport in groundwater and surface waters, groundwater balance and depletion, seawater intrusion, and more.

This picture shows that groundwater vulnerability assessment based on contaminant transport modeling can provide more quantitative evaluation than previously discussed rating methods. On the other hand, the model's large number of input parameters and the uncertainty associated with them may be considerable issues. In fact, to implement such simulations, an accurate characterization of all flow and transport processes acting at a given site is a prerequisite, and, in addition, there is also the need to deeply understand the geochemical environment [144].

Despite this, the possible applications of numerical models are quite numerous. Some examples of aquifer vulnerability to $\mathrm{NO}_{3}{ }^{-}$measured using MODFLOW/MT3DMS models are found in USA [145], Europe [146], and Africa [147]. Uhan et al. [148], assessed $\mathrm{NO}_{3}{ }^{-}$ groundwater vulnerability for an alluvial aquifer combining the output of three different numerical models: (i) groundwater recharge (GROWA), (ii) $\mathrm{NO}_{3}{ }^{-}$leached from the soil profile (SWAT), and (iii) groundwater flow velocities (FEFLOW). Cui et al. [149] assessed the whole Florida shallow aquifer vulnerability through the $\mathrm{Nr}$ removal and transport rate in the unsaturated zone. Hansen et al. [150] developed the site-specific concept for aquifer nitrate vulnerability assessment (SCANVA) through the combination of a 3D geological reconstruction, a groundwater simulation based on MODFLOW-2000, and a complete hydro-geochemical assessment. Huan et al. [151-153] proposed a specific vulnerability assessment using HYDRUS-1D model and FEFLOW, emphasizing the role of DNT within the unsaturated zone using an enhanced convection-dispersion equation. The $\mathrm{Nr}$ transfer time and $\mathrm{NO}_{3}{ }^{-}$susceptibility in pumping wells were finally used to visualize the specific vulnerability.

\subsection{Hybrid Methodologies}

Some authors tried to enhance the results of the assessment of vulnerability to $\mathrm{NO}_{3}{ }^{-}$, combining classical rating methods along with process-based and statistical elaborations. Sometimes, these new hybridizations introduced new parameters related to DNT that are usually not considered in the standard methodologies. Keuskamp et al. [68] hybridized $\mathrm{N}$ budget with a basin-scale process-based model to simulate the fate of $\mathrm{Nr}$ in soils and groundwater, along with $\mathrm{N}_{2} \mathrm{O}$ production at the European scale. The model offers the output calculation of travel time, which integrates in its computation the DNT rate for the main European countries. Aschonitis et al. [154,155] developed a simplistic N-budget approach described by indices named LOS, which account for DNT, $\mathrm{NH}_{3}$ volatilization, mineralization, and nitrification. The new indices involve detailed information on landscape management and climate and are calibrated using the results of a GLEAMS model thought regression analysis. Kazakis and Voudouris [156], following the example of Huan et al. [157], who subjectivized the DRASTIC framework, replaced some parameters in the DRASTIC-PAN methodology. This new method, integrated within the LOS indices, indicates the soil $\mathrm{Nr}$ losses based on climatic, soil, and topographic data. Similarly, Bu- 
sico et al. $[11,158]$ hybridized the SINTACS method, called SINTACS-SVN and SVAP, introducing the LOS indices inside the evaluation process to assess intrinsic and specific groundwater vulnerability to $\mathrm{NO}_{3}{ }^{-}$and $\mathrm{SO}_{4}{ }^{2-}$ pollution. In both methodologies, the weights and scores were calibrated using observed $\mathrm{NO}_{3}{ }^{-}$concentrations and pollution factors following the routine of canonical process-based methodologies, making the evaluation less subjective than standard rating methods. These indices proved to produce reliable results in different hydrogeological settings [159]. Jia et al. [160] developed the DRANTHVP method, optimizing weights and rates of the DRASTIC method by using the statistical analysis of projection pursuit dynamic clustering (PPDC). Moreover, during the choice of parameters, the authors introduced the $\mathrm{NO}_{3}{ }^{-}$attenuation factor to replace the soil media factor. The proposed classification is based on the difference of soil moisture content, porosity, and organic matter content, factors that are directly linked to DNT rate [161,162]. Vouthckova et al. [163] integrated subsurface redox conditions inside the DRASTIC classification. This parameter is considered indicative of DNT as the $\mathrm{NO}_{3}{ }^{-}$ removal by microbial oxidation depends on the availability of reductants species, such as pyrite and organic matter [164].

\section{Concluding Remarks}

The assessment of groundwater vulnerability to $\mathrm{NO}_{3}{ }^{-}$is a valuable tool for the implementation of sustainable groundwater management plans. However, the standard intrinsic vulnerability assessment methods can lead to unreliable results, since they do not consider all $\mathrm{NO}_{3}{ }^{-}$attenuation processes occurring in both the unsaturated and saturated zones, as proved by validation procedures using observed $\mathrm{NO}_{3}{ }^{-}$concentrations providing feedback on the reliability of the applied methodology. Accordingly, in the last 20 years, the classical rating methodologies have been deeply modified to account for the pollutant dilution and attenuation processes, with the aim of enhancing their reliability. Still, the analysis of all the studies considered in this review has shown that almost $50 \%$ of groundwater vulnerability assessments are performed using rating methodologies, followed by statistical methods, numerical models, and hybrid methods (Figure 4).

\section{- Rating methods - Statistical methods $"$ Numerical model $"$ Hybrid methods}

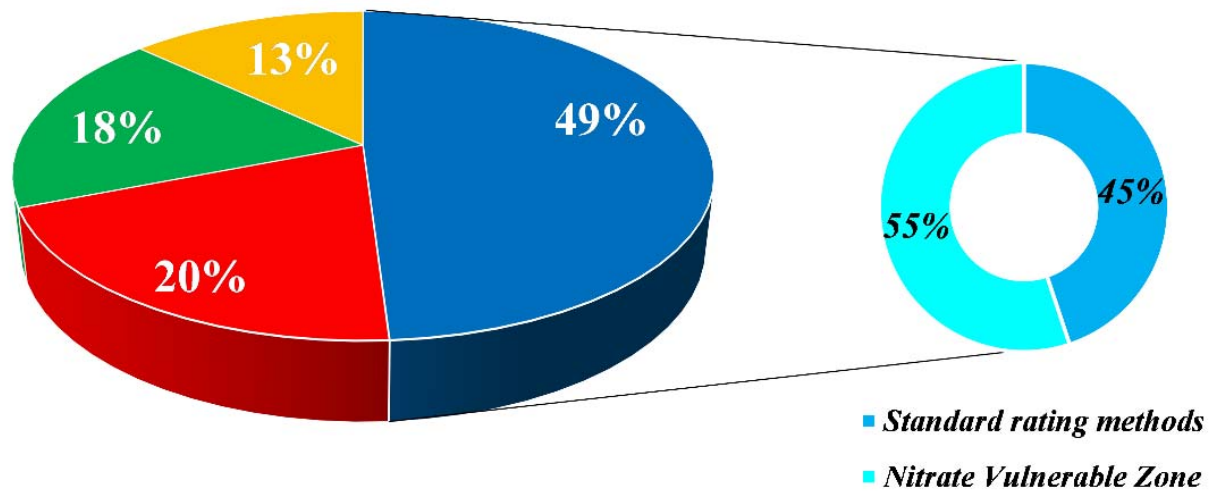

Figure 4. General statistics for the discusses categories.

The reason for this result is likely due to the low data requirement and simplicity of elaboration needed for the rating methodologies with respect to the other methods. Inside the group of rating methodologies (Figure 3), the NVZ applications introduced some parameters directly connected to DNT, such as soil organic carbon, agricultural practices, and $\mathrm{Nr}$ input, but still retained the structure of a classical rating method. Indeed, 
in the NVZ methods, most of the studies used a spatial representation of the validation procedure, projecting the $\mathrm{NO}_{3}{ }^{-}$concentrations over the vulnerability classification, but without accounting for groundwater travel times.

On the other hand, in the statistical and numerical models, the concept of validation is intrinsically linked to the model structures. Numerical models require validation on multiple steps and are always preceded by calibration procedures aimed at quantifying the model's ability to simulate the real system. The statistical methods follow the same concept of calibration and validation procedures, where the spatial distribution of the so-called explanatory variable (aquifer type, soil characteristics, agricultural $\mathrm{Nr}$ load, and land cover) is discretized according to water quality. Moreover, statistical methods always consider observed data (pollutant concentration, dissolved oxygen, soil $\mathrm{pH}$, and more) in the evaluation process. Unfortunately, due to their complex structure and necessity of specific data, they are mainly confined to site-specific assessments, even if some examples of regional and continental applications exist. Similarly, the hybrid methods suffer from a complex structure, often based on regression analysis and statistical correlation, demanding more data and sometimes requiring specific outputs produced by complex numerical models. Despite the increased complexity, the hybrid methodologies showed a higher reliability, confirmed by the validation procedure performed in all the studies.

\subsection{The Role of Denitrification in Groundwater Vulnerability Assessment}

In summary, it is possible to state that the involvement of $\mathrm{NO}_{3}{ }^{-}$decay processes in the evaluation of groundwater vulnerability assessment, and specifically of DNT, directly increased the final reliability of the vulnerability evaluation. This is particularly evident in rating applications, where the methodologies that lumped the parameters directly connected with DNT showed better results than standard DRASTIC, SINTACS, AVI, or GOD methods $[11,117,156,158,160]$. However, this improvement pays the price for an increase in model complexity and data requirement, a common drawback also for numerical and statistical models.

Thanks to the recent increase in the availability of online and free datasets, required by open science and open data protocols, such drawbacks could be overcome in future studies. For example, Keuskamp et al. [68] provided an average yearly DNT rate on the river basin scale, which can be easily incorporated in statistical and numerical models. Also, Kumar et al. [7] proposed a $\mathrm{NO}_{3}{ }^{-}$leaching assessment on the European scale. The results of these computations, along with many others, could be eventually used to enhance site assessment vulnerability to $\mathrm{NO}_{3}{ }^{-}$, even in those areas where a direct measurement of DNT rates is not available. Furthermore, where data are scant, new approaches to evaluate groundwater vulnerability have been recently proposed [165] that leave behind the concept of rating methods to consider $\mathrm{NO}_{3}{ }^{-}$contamination, suggesting specific sub-indicators of exposure, sensitivity, and adaptive capacity according to the indications of the Intergovernmental Panel on Climate Change [166,167].

Summarizing, standard vulnerability methods, not considering all the biogeochemical processes occurring both in the saturated and unsaturated zones, still represent precious screening tools for a qualitative assessment of aquifer vulnerability especially at large scales, but when there is a need to gain quantitative, reliable, and time-dependent vulnerability assessments, the employment of more complex data- and time-requiring methodologies must be preferred.

\subsection{Future Trends in the Application of Groundwater Vulnerability Assessment}

The economic and social significance of a good land and water management is an overarching goal in the UN 2030 Agenda for sustainable development. Fundamental changes in the way societies produce and use natural resources are indispensable for achieving the sustainable development goals (SDGs) within the carrying capacity of ecosystems that provide essential services, which are critical for human well-being. 
For this to happen, good governance and safeguarding of land and water resources should be implemented in an integrated manner, involving all stakeholders and building monitoring and assessment tools based on sound, scientifically formulated knowledge. For instance, boosting yields and protecting crops to assure food production has often been achieved via the extensive use of agrochemicals (fertilizers, pesticides, etc.), with the consequence that many aquifers in heavily anthropized lowlands record high values of these contaminants and, thus, have recently been classified as NVZ. To adequately address these issues, decision makers must look at the latest scientific knowledge, which can support productive food systems (e.g., SDGs 2 and 12) through sustainable soil, land, water, nutrient, and pest management. Refining the groundwater vulnerability assessment methods, including DNT in the evaluation process, goes precisely in this direction.

In this context, future studies should be carried out focusing on the 'source-pathwaytarget' approach [168], where source indicates potential contamination due to land-use activities, pathway refers to the fate and transport of contaminants from the source to the target, and the target is the environment receiving the contamination load. In the specific case of groundwater vulnerability, the pathway should be identified in the movement of the infiltrating water across the unsaturated zone and within the saturated zone, while the target could be identified in the aquifer itself and in the groundwater-dependent ecosystems (GDEs), which could be endangered by the high concentration of pollutants discharging from the aquifer to the surface water bodies. It is known that the concentration of pollutants depends on the characteristics of the source (loading rate and duration) but also on the characteristics of the pathway where dilution, dispersion, and/or attenuation may occur. For this specific reason, it is fundamental to include an explicit evaluation of DNT rates for the saturated and unsaturated zones to account for the attenuation capacity of the pathway [11,42]. Although the monitoring and characterization of the unsaturated zone is complex and time consuming, future studies need to fulfill this task to gain more realistic estimates in groundwater vulnerability assessments [38]. Moreover, since the processes occurring along the pathway are also highly variable in time and space [30], there is a need for improved understanding of DNT rate variability over the hydrologic year, both as a function of the natural seasonality of the attenuation processes and as a function of the different agricultural practices that are carried out at specific times of the year (fertilization, plowing, harvesting, etc.), which, in turn, may affect the factors controlling DNT in the unsaturated/saturated zones. Based on this information, it will be necessary to implement the groundwater vulnerability assessment tools with approaches and techniques that are able to account for this seasonality (like numerical models).

This improvement will lead to great benefits, especially in the management of land and water resources in GDEs [169]. In fact, GDEs are often located in flat coastal areas (e.g., wetlands, swamps, riverine plains, etc.) that are also ideal environments for agricultural activities [170]. This combination makes most of these habitats prone to adverse effects of water pollution induced by human activities. One of the most common examples is the establishment of eutrophication conditions due to excessive $\mathrm{N}$ load that may lead to the death of aquatic species. For this reason, the systematic mapping of groundwater vulnerability, accounting also for the fate of $\mathrm{N}$ species (thus including DNT), must be promoted to develop land uses and human activities according to the groundwater vulnerability, responding to important SDGs of the 2030 Agenda (e.g., SDGs 14 and 15).

Finally, the recent tendency to improve the reliability of the methods considered in this review and the definition of new approaches for groundwater vulnerability assessment demonstrates that a sound tool to properly manage water resources is considered necessary and urgent, not only by the wider research community, but even by decision makers and land and water managers. In particular, the most coveted result is to provide a userfriendly tool based on the latest scientific knowledge, which would allow the definition of management plans capable of considering the most effective allocation of mitigation strategies and achieving the highest reduction of adverse impacts within a relatively short time and available budgets. 
Author Contributions: Conceptualization, M.M. and G.B.; methodology, G.B.; software, L.A.; validation, M.M.; formal analysis, G.B. and L.A.; resources, G.B. and M.M.; data curation, G.B. and L.A.; writing - original draft preparation, G.B.; writing-review and editing, M.M.; visualization, G.B. and M.M.; supervision, M.M. All authors have read and agreed to the published version of the manuscript.

Funding: This research received no external funding.

Institutional Review Board Statement: Not applicable.

Informed Consent Statement: Not applicable.

Data Availability Statement: The data presented in this study are available on request from the corresponding author. The data are not publicly available due to the Scopus database restriction access only to subscribers.

Conflicts of Interest: The authors declare no conflict of interest.

\section{References}

1. Han, D.; Currell, M.J.; Cao, G. Deep challenges for China's war on water pollution. Environ. Pollut. 2016, 218, 1222-1233. [CrossRef] [PubMed]

2. Kut, K.M.K.; Sarswat, A.; Srivastava, A.; Pittman, C.U.; Mohan, D. A review of fluoride in african groundwater and local remediation methods. Groundw. Sustain. Dev. 2016, 2-3, 190-212. [CrossRef]

3. Burri, N.M.; Weatherl, R.; Moeck, C.; Schirmer, M. A review of threats to groundwater quality in the Anthropocene. Sci. Total Environ. 2019, 684, 136-154. [CrossRef]

4. Kurwadkar, S. Emerging Trends in Groundwater Pollution and Quality. Water Environ. Res. 2014, 86, 1677-1691. [CrossRef]

5. Kristensen, P.; Whalley, C.; Néry, F.; Zal, N.; Christiansen, T. European Waters-Assessment of Status and Pressures 2018; EEA Report No. 7/2018; European Environment Agency: Copenhagen, Denmark, 2018. [CrossRef]

6. Gorelick, S.M.; Zheng, C. Global change and the groundwater management challenge. Water Resour. Res. 2015, 51, 3031-3051. [CrossRef]

7. Kumar, R.; Heße, F.; Rao, P.S.C.; Musolff, A.; Jawitz, J.W.; Sarrazin, F.; Samaniego, L.; Fleckenstein, J.H.; Rakovec, O.; Thober, S.; et al. Strong hydroclimatic controls on vulnerability to subsurface nitrate contamination across Europe. Nat. Commun. 2020, 11, 6302. [CrossRef] [PubMed]

8. Ascott, M.J.; Gooddy, D.C.; Wang, L.; Stuart, M.E.; Lewis, M.A.; Ward, R.S.; Binley, A.M. Global patterns of nitrate storage in the vadose zone. Nat. Commun. 2017, 8, 1416. [CrossRef]

9. Erisman, J.W.; Galloway, J.N.; Seitzinger, S.; Bleeker, A.; Dise, N.B.; Petrescu, A.M.R.; Leach, A.M.; de Vries, W. Consequences of human modification of the global nitrogen cycle. Philos. Trans. R Soc. B Biol. Sci. 2013, 368, 20130116. [CrossRef]

10. Liu, G.D.; Wu, W.L.; Zhang, J. Regional differentiation of non-point source pollution of agriculture-derived nitrate nitrogen in groundwater in northern China. Agric. Ecosyst. Environ. 2005, 107, 211-220. [CrossRef]

11. Busico, G.; Kazakis, N.; Colombani, N.; Khosravi, K.; Voudouris, K.; Mastrocicco, M. The Importance of Incorporating Denitrification in the Assessment of Groundwater Vulnerability. Appl. Sci. 2020, 10, 2328. [CrossRef]

12. Steffen, W.; Richardson, K.; Rockstrom, J.; Cornell, S.E.; Fetzer, I.; Bennett, E.M.; Biggs, R.; Carpenter, S.R.; de Vries, W.; de Wit, C.A.; et al. Planetary boundaries: Guiding human development on a changing planet. Science 2015, 347, 1259855. [CrossRef] [PubMed]

13. Manassaram, D.M.; Backer, L.C.; Messing, R.; Fleming, L.E.; Luke, B.; Monteilh, C.P. Nitrates in drinking water and methemoglobin levels in pregnancy: A longitudinal study. Environ. Health 2010, 9, 60. [CrossRef]

14. Morée, A.L.; Beusen, A.H.W.; Bouwman, A.F.; Willems, W.J. Exploring global nitrogen and phosphorus flows in urban wastes during the twentieth century. Glob. Biogeochem. Cycles 2013, 27, 836-846. [CrossRef]

15. U.S. Environmental Protection Agency. 2018 Edition of the Drinking Water Standards and Health Advisories Tables; Office of Water-U.S. EPA: Washington, DC, USA, 2018.

16. European Union Council. Council Directive 98/83/EC of 3 November 1998 on the Quality of Water Intended for Human Consumption. Off. J. Eur. Union 1998, 330, 32-54.

17. Seitzinger, S.; Harrison, J.A.; Böhlke, J.K.; Bouwman, A.F.; Lowrance, R.; Peterson, B.; Tobias, C.; Drecht, G.V. Denitrification across landscapes and waterscapes: A synthesis. Ecol. Appl. 2006, 16, 2064-2090. [CrossRef]

18. Debernardi, L.; De Luca, D.A.; Lasagna, M. Correlation between nitrate concentration in groundwater and parameters affecting aquifer intrinsic vulnerability. Environ. Geol. 2008, 55, 539-558. [CrossRef]

19. Otero, N.; Torrentó, C.; Soler, A.; Menció, A.; Mas-Pla, J. Monitoring groundwater nitrate attenuation in a regional system coupling hydrogeology with multi-isotopic methods: The case of Plana de Vic (Osona, Spain). Agric. Ecosyst. Environ. 2009, 133, 103-113. [CrossRef]

20. Yoon, S.; Song, B.; Phillips, R.L.; Chang, J.; Song, M.J. Ecological and physiological implications of nitrogen oxide reduction pathways on greenhouse gas emissions in agroecosystems. FEMS Microbiol. Ecol. 2019, 95. [CrossRef] 
21. Silver, W.L.; Herman, D.J.; Firestone, M.K. Dissimilatory nitrate reduction to ammonium in upland tropical forest soils. Ecology 2001, 82, 2410-2416. [CrossRef]

22. Kartal, B.; Kuypers, M.M.M.; Lavik, G.; Schalk, J.; Op den Camp, H.J.M.; Jetten, M.S.M.; Strous, M. Anammox bacteria disguised as denitrifiers: Nitrate reduction to dinitrogen gas via nitrite and ammonium. Environ. Microbiol. 2007, 9, 635-642. [CrossRef]

23. Di Capua, F.; Pirozzi, F.; Lens, P.N.L.; Esposito, G. Electron donors for autotrophic denitrification. Chem. Eng. J. 2019, 362, 922-937. [CrossRef]

24. Dinnes, D.L.; Karlen, D.L.; Jaynes, D.B.; Kaspar, T.C.; Hatfield, J.L.; Colvin, T.S.; Cambardella, C.A. Nitrogen Management Strategies to Reduce Nitrate Leaching in Tile-Drained Midwestern Soils. Agron. J. 2002, 94, 153. [CrossRef]

25. Biddau, R.; Cidu, R.; Da Pelo, S.; Carletti, A.; Ghiglieri, G.; Pittalis, D. Source and fate of nitrate in contaminated groundwater systems: Assessing spatial and temporal variations by hydrogeochemistry and multiple stable isotope tools. Sci. Total Environ. 2019, 647, 1121-1136. [CrossRef]

26. Liu, C.-Q.; Li, S.-L.; Lang, Y.-C.; Xiao, H.-Y. Using $\delta 15 \mathrm{~N}$ - and $\delta 18$ O-Values To Identify Nitrate Sources in Karst Ground Water, Guiyang, Southwest China. Environ. Sci. Technol. 2006, 40, 6928-6933. [CrossRef]

27. Kazakis, N.; Matiatos, I.; Ntona, M.-M.; Bannenberg, M.; Kalaitzidou, K.; Kaprara, E.; Mitrakas, M.; Ioannidou, A.; Vargemezis, G.; Voudouris, K. Origin, implications and management strategies for nitrate pollution in surface and ground waters of Anthemountas basin based on a $\delta 15 \mathrm{~N}_{-} \mathrm{NO}_{3}{ }^{-}$and $\delta 18 \mathrm{O}-\mathrm{NO}_{3}{ }^{-}$isotope approach. Sci. Total Environ. 2020, 724, 138211. [CrossRef] [PubMed]

28. Busico, G.; Cuoco, E.; Kazakis, N.; Colombani, N.; Mastrocicco, M.; Tedesco, D.; Voudouris, K. Multivariate statistical analysis to characterize/discriminate between anthropogenic and geogenic trace elements occurrence in the Campania Plain, Southern Italy. Environ. Pollut. 2018, 234, 260-269. [CrossRef]

29. Wijayanti, Y.; Nakamura, T.; Nishida, K.; Haramoto, E.; Sakamoto, Y. Seasonal Differences and Source Estimation of Groundwater Nitrate Contamination. J. Water Environ. Technol. 2013, 11, 163-174. [CrossRef]

30. Jin, L.; Whitehead, P.G.; Futter, M.N.; Lu, Z. Modelling the impacts of climate change on flow and nitrate in the River Thames: Assessing potential adaptation strategies. Hydrol. Res. 2012, 43, 902-916. [CrossRef]

31. Menció, A.; Boy, M.; Mas-Pla, J. Analysis of vulnerability factors that control nitrate occurrence in natural springs (Osona Region, NE Spain). Sci. Total Environ. 2011, 409, 3049-3058. [CrossRef]

32. Álvarez-Cabria, M.; Barquín, J.; Peñas, F.J. Modelling the spatial and seasonal variability of water quality for entire river networks: Relationships with natural and anthropogenic factors. Sci. Total Environ. 2016, 545-546, 152-162. [CrossRef]

33. Vigliotti, M.; Busico, G.; Ruberti, D. Assessment of the Vulnerability to Agricultural Nitrate in Two Highly Diversified Environmental Settings. Environments 2020, 7, 80. [CrossRef]

34. Jha, M.K.; Chowdhury, A.; Chowdary, V.M.; Peiffer, S. Groundwater management and development by integrated remote sensing and geographic information systems: Prospects and constraints. Water Resour. Manag. 2007, 21, 427-467. [CrossRef]

35. Vrba, J.; Zaporozec, A. Guidebook on mapping groundwater vulnerability. In IAH International Contributions to Hydrogeology; Heise Pub: Hannover, Germany, 1994; Volume 16.

36. Foster, S.; Hirata, R.; Andreo, B. The aquifer pollution vulnerability concept: Aid or impediment in promoting groundwater protection? Hydrogeol. J. 2013, 21, 1389-1392. [CrossRef]

37. National Research Council. Groundwater Vulnerability Assessment_Predicting Relative Contamination Potential under Conditions of Uncertainty; National Academy Press: Washington, DC, USA, 1993. [CrossRef]

38. Machiwal, D.; Jha, M.K.; Singh, V.P.; Mohan, C. Assessment and mapping of groundwater vulnerability to pollution: Current status and challenges. Earth-Sci. Rev. 2018, 185, 901-927. [CrossRef]

39. Behrend, H.; Opitz, D. Retention of nutrients in river systems: Dependence on specific runoff and hydraulic load. In Man and River Systems. Developments in Hydrobiology; Garnier, J., Mouchel, J.M., Eds.; Springer: Dordrecht, The Netherlands, 1999; pp. 111-122. [CrossRef]

40. Bicking, S.; Steinhoff-Knopp, B.; Burkhard, B.; Müller, F. Quantification and mapping of the nutrient regulation ecosystem service demand on a local scale. Ecosyst. People 2020, 16, 114-134. [CrossRef]

41. Kersebaum, K.C.; Matzdorf, B.; Kiesel, J.; Piorr, A.; Steidl, J. Model-based evaluation of agri-environmental measures in the Federal State of Brandenburg (Germany) concerning N pollution of groundwater and surface water. J. Plant Nutr. Soil Sci. 2006, 169, 352-359. [CrossRef]

42. Lasagna, M.; De Luca, D.A.; Franchino, E. The role of physical and biological processes in aquifers and their importance on groundwater vulnerability to nitrate pollution. Environ. Earth Sci. 2016, 75, 961. [CrossRef]

43. Lasagna, M.; De Luca, D.A.; Franchino, E. Intrinsic groundwater vulnerability assessment: Issues, comparison of different methodologies and correlation with nitrate concentrations in NW Italy. Environ. Earth Sci. 2018, 77, 277. [CrossRef]

44. Rivett, M.O.; Buss, S.R.; Morgan, P.; Smith, J.W.N.; Bemment, C.D. Nitrate attenuation in groundwater: A review of biogeochemical controlling processes. Water Res. 2008, 42, 4215-4232. [CrossRef]

45. Akiyama, H.; Yan, X.; Yagi, K. Evaluation of effectiveness of enhanced-efficiency fertilizers as mitigation options for $\mathrm{N}_{2} \mathrm{O}$ and $\mathrm{NO}$ emissions from agricultural soils: Meta-analysis. Glob. Chang. Biol. 2009, 16, 1837-1846. [CrossRef]

46. Šimek, M.; Cooper, J.E.; Picek, T.; Šantrůčková, H. Denitrification in arable soils in relation to their physico-chemical properties and fertilization practice. Soil Biol. Biochem. 2000, 32, 101-110. [CrossRef]

47. Li, X.; Hu, C.; Delgado, J.A.; Zhang, Y.; Ouyang, Z. Increased nitrogen use efficiencies as a key mitigation alternative to reduce nitrate leaching in north china plain. Agric. Water Manag. 2007, 89, 137-147. [CrossRef] 
48. D'Haene, K.; Moreels, E.; De Neve, S.; Chaves Daguilar, B.; Boeckx, P.; Hofman, G.; Van Cleemput, O. Soil properties influencing the denitrification potential of Flemish agricultural soils. Biol. Fertil. Soils 2003, 38, 358-366. [CrossRef]

49. Ma, B.L.; Wu, T.Y.; Tremblay, N.; Deen, W.; Morrison, M.J.; Mclaughlin, N.B.; Gregorich, E.G.; Stewart, G. Nitrous oxide fluxes from corn fields: On-farm assessment of the amount and timing of nitrogen fertilizer. Glob. Chang. Biol. 2010, 16, 156-170. [CrossRef]

50. Lebender, U.; Senbayram, M.; Lammel, J.; Kuhlmann, H. Impact of mineral $\mathrm{N}$ fertilizer application rates on $\mathrm{N}_{2} \mathrm{O}$ emissions from arable soils under winter wheat. Nutr. Cycl. Agroecosyst. 2014, 100, 111-120. [CrossRef]

51. Castaldelli, G.; Colombani, N.; Vincenzi, F.; Mastrocicco, M. Linking dissolved organic carbon, acetate and denitrification in agricultural soils. Environ. Earth Sci. 2013, 68, 939-945. [CrossRef]

52. Colombani, N.; Mastrocicco, M.; Vincenzi, F.; Castaldelli, G. Modeling Soil Nitrate Accumulation and Leaching in Conventional and Conservation Agriculture Cropping Systems. Water 2020, 12, 1571. [CrossRef]

53. Jahangir, M.M.R.; Fenton, O.; Müller, C.; Harrington, R.; Johnston, P.; Richards, K.G. In situ denitrification and DNRA rates in groundwater beneath an integrated constructed wetland. Water Res. 2017, 111, 254-264. [CrossRef]

54. Almaraz, M.; Wong, M.Y.; Yang, W.H. Looking back to look ahead: A vision for soil denitrification research. Ecology 2020, 101, e02917. [CrossRef]

55. Gorski, G.; Dailey, H.; Fisher, A.T.; Schrad, N.; Saltikov, C. Denitrification during infiltration for managed aquifer recharge: Infiltration rate controls and microbial response. Sci. Total Environ. 2020, 727, 138642. [CrossRef]

56. Watts, S.H.; Seitzinger, S.P. Denitrification rates in organic and mineral soils from riparian sites: A comparison of $\mathrm{N}_{2}$ flux and acetylene inhibition methods. Soil Biol. Biochem. 2000, 32, 1383-1392. [CrossRef]

57. Pinay, G.; Gumiero, B.; Tabacchi, E.; Gimenez, O.; Tabacchi-Planty, A.M.; Hefting, M.M.; Burt, T.P.; Black, V.A.; Nilsson, C.; Iordache, V.; et al. Patterns of denitrification rates in European alluvial soils under various hydrological regimes. Freshw. Biol. 2007, 52, 252-266. [CrossRef]

58. Tan, X.; Shao, D.; Gu, W. Effects of temperature and soil moisture on gross nitrification and denitrification rates of a Chinese lowland paddy field soil. Paddy Water Environ. 2018, 16, 687-698. [CrossRef]

59. Groffman, P.M.; Turner, C.L. Plant productivity and nitrogen gas fluxes in a tallgrass prairie landscape. Landsc. Ecol. 1995, 10, 255-266. [CrossRef]

60. Li, B.; Chen, J.; Wu, Z.; Wu, S.; Xie, S.; Liu, Y. Seasonal and spatial dynamics of denitrification rate and denitrifier community in constructed wetland treating polluted river water. Int. Biodeterior. Biodegrad. 2018, 126, 143-151. [CrossRef]

61. Ruz-Jerez, B.E.; White, R.E.; Ball, P.R. Long-term measurement of denitrification in three contrasting pastures grazed by sheep. Soil Biol. Biochem. 1994, 26, 29-39. [CrossRef]

62. Bragan, R.J.; Starr, J.L.; Parkin, T.B. Shallow Groundwater Denitrification Rate Measurement by Acetylene Block. J. Environ. Qual. 1997, 26, 1531-1538. [CrossRef]

63. Singh, B.; Ryden, J.C.; Whitehead, D.C. Denitrification potential and actual rates of denitrification in soils under long-term grassland and arable cropping. Soil Biol. Biochem. 1989, 21, 897-901. [CrossRef]

64. Elmi, A.A.; Madramootoo, C.; Hamel, C. Influence of water table and nitrogen management on residual soil $\mathrm{NO}_{3}{ }^{-}$and denitrification rate under corn production in sandy loam soil in Quebec. Agric. Ecosyst. Environ. 2000, 79, 187-197. [CrossRef]

65. van Beek, C.L.; Hummelink, E.W.J.; Velthof, G.L.; Oenema, O. Denitrification rates in relation to groundwater level in a peat soil under grassland. Biol. Fertil. Soils 2004, 39, 329-336. [CrossRef]

66. Barton, L.; McLay, C.D.A.; Schipper, L.A.; Smith, C.T. Denitrification Rates in a Wastewater-Irrigated Forest Soil in New Zealand. J. Environ. Qual. 1999, 28, 2008-2014. [CrossRef]

67. Mohn, J.; Schürmann, A.; Hagedorn, F.; Schleppi, P.; Bachofen, R. Increased rates of denitrification in nitrogen-treated forest soils. For. Ecol. Manag. 2000, 137, 113-119. [CrossRef]

68. Keuskamp, J.A.; van Drecht, G.; Bouwman, A.F. European-scale modelling of groundwater denitrification and associated $\mathrm{N}_{2} \mathrm{O}$ production. Environ. Pollut. 2012, 165, 67-76. [CrossRef]

69. Estavillo, J.M.; Rodriguez, M.; Domingo, M.; Munoz-Rueda, A.; Gonzalez-Murua, C. Denitrification losses from a natural grassland in the Basque Country under organic and inorganic fertilization. Plant Soil 1994, 162, 19-29. [CrossRef]

70. Ryden, J.C.; Lund, L.J. Nature and Extent of Directly Measured Denitrification Losses from Some Irrigated Vegetable Crop Production Units. Soil Sci. Soc. Am. J. 1980, 44, 505-511. [CrossRef]

71. Ledgard, S.F.; Penno, J.W.; Sprosen, M.S. Nitrogen balances and losses on intensive dairy farms. Proc. N. Z. Grassl. Assoc. 1997, 49-53. [CrossRef]

72. Schwarz, L.; Kapp, M.; Benckiser, G.; Ottow, J.C.G. Evaluation of denitrification losses by the acetylene inhibition technique in a permanent ryegrass field (Lolium perenne L.) fertilized with animal slurry or ammonium nitrate. Biol. Fertil. Soils 1994, 18, 327-333. [CrossRef]

73. De Klein, C.A.M.; Van Logtestijn, R.S.P. Denitrification in the top soil of managed grasslands in The Netherlands in relation to soil type and fertilizer level. Plant Soil 1994, 163, 33-44. [CrossRef]

74. Schnabel, R.R.; Stout, W.L. Denitrification Loss from Two Pennsylvania Floodplain Soils. J. Environ. Qual. 1994, $23,344-348$. [CrossRef]

75. Aulakh, M.S.; Rennie, D.A.; Paul, E.A. The Influence of Plant Residues on Denitrification Rates in Conventional and Zero Tilled Soils. Soil Sci. Soc. Am. J. 1984, 48, 790-794. [CrossRef] 
76. Myrold, D.D. Denitrification in Ryegrass and Winter Wheat Cropping Systems of Western Oregon. Soil Sci. Soc. Am. J. 1988, 52, 412-416. [CrossRef]

77. Aller, L.; Bennet, T.; Lehr, J.H.; Petty, R.J.; Hackett, G. DRASTIC: A Standardized System for Evaluating Ground-Water Pollution Potential Using Hydrogeologic Settings; U.S. Environmental Protection Agency: Washington, DC, USA, 1987.

78. Foster, S.S.D. Fundamental concepts in aquifer vulnerability, pollution risk and protection strategy. In Vulnerability of Soil and Groundwater to Pollutants; Van Duijvenbooden, W., Van Waegeningh, H.G., Eds.; Committee on Hydrological Research: The Hague, The Netherlands, 1987; pp. 69-86.

79. Stempvoort, D.V.; Ewert, L.; Wassenaar, L. Aquifer Vulnerability Index: A Gis-Compatible Method For Groundwater Vulnerability Mapping. Can. Water Resour. J. 1993, 18, 25-37. [CrossRef]

80. Doerfliger, N.; Jeannin, P.-Y.; Zwahlen, F. Water vulnerability assessment in karst environments: A new method of defining protection areas using a multi-attribute approach and GIS tools (EPIK method). Environ. Geol. 1999, 39, 165-176. [CrossRef]

81. Civita, M.; De Maio, M. Assessing and mapping groundwater vulnerability to contamination: The Italian "combined" approach. Geofis. Int. 2004, 43, 513-532. [CrossRef]

82. Moore, P.; John, S. SEEPAGE: A System for Early Evaluation of the Pollution Potential of Agricultural Groundwater Environments; Geology Technical Note; USDA, SCS, Northeast Technical Center: Chester, PA, USA, 1990.

83. Ouedraogo, I.; Defourny, P.; Vanclooster, M. Mapping the groundwater vulnerability for pollution at the pan African scale. Sci. Total Environ. 2016, 544, 939-953. [CrossRef]

84. Fakhri, M.S.; Moghaddam, A.A.; Najib, M.; Barzegar, R. Investigation on nitrate concentrations in groundwater resources of marand plain and groundwater vulnerability assessment using AVI and GODS methods. J. Environ. Stud. 2015, 41, 49-66.

85. Hamza, S.M.; Ahsan, A.; Imteaz, M.A.; Rahman, A.; Mohammad, T.A.; Ghazali, A.H. Accomplishment and subjectivity of GIS-based DRASTIC groundwater vulnerability assessment method: A review. Environ. Earth Sci. 2015, 73, 3063-3076. [CrossRef]

86. Shrestha, S.; Kafle, R.; Pandey, V.P. Evaluation of index-overlay methods for groundwater vulnerability and risk assessment in Kathmandu Valley, Nepal. Sci. Total Environ. 2017, 575, 779-790. [CrossRef] [PubMed]

87. Busico, G.; Cuoco, E.; Sirna, M.; Mastrocicco, M.; Tedesco, D. Aquifer vulnerability and potential risk assessment: Application to an intensely cultivated and densely populated area in Southern Italy. Arab. J. Geosci. 2017, 10, 222. [CrossRef]

88. Hu, M.; Peñuelas, J.; Sardans, J.; Huang, J.; Xu, K.; Tong, C. Denitrification rates in tidal marsh soils: The roles of soil texture, salinity and nitrogen enrichment. Eur. J. Soil Sci. 2021, 72, 474-479. [CrossRef]

89. Palta, M.M.; Ehrenfeld, J.G.; Giménez, D.; Groffman, P.M.; Subroy, V. Soil texture and water retention as spatial predictors of denitrification in urban wetlands. Soil Biol. Biochem. 2016, 101, 237-250. [CrossRef]

90. Navulur, K.C.S.; Engel, B.A. Groundwater vulnerability assessment to non-point source nitrate pollution on a regional scale using gis. Trans. ASAE 1998, 41, 1671-1678. [CrossRef]

91. Jang, W.; Engel, B.; Harbor, J.; Theller, L. Aquifer Vulnerability Assessment for Sustainable Groundwater Management Using DRASTIC. Water 2017, 9, 792. [CrossRef]

92. Pacheco, F.A.L.; Sanches Fernandes, L.F. The multivariate statistical structure of DRASTIC model. J. Hydrol. 2013, 476, 442-459. [CrossRef]

93. Garewal, S.K.; Vasudeo, A.D.; Ghare, A.D. Optimization of the GIS-Based DRASTIC Model for Groundwater Vulnerability Assessment. In Nature-Inspired Methods for Metaheuristics Optimization; Springer: Berlin/Heidelberg, Germany, 2020; pp. 489-502. [CrossRef]

94. Asefi, M.; Radmanesh, F.; Zarei, H. Optimization of DRASTIC and SINTACS models according to geographical information system with the use of Analytical Hierarchy Process (AHP) (Case study: Andimeshk Plain). J. Environ. Stud. 2014, 40, 79-94. [CrossRef]

95. Goudarzi, S.; Jozi, S.A.; Monavari, S.M.; Karbasi, A.; Hasani, A.H. Assessment of groundwater vulnerability to nitrate pollution caused by agricultural practices. Water Qual. Res. J. 2017, 52, 64-77. [CrossRef]

96. Sullivan, T.P.; Gao, Y. Development of a new P3 (Probability, Protection, and Precipitation) method for vulnerability, hazard, and risk intensity index assessments in karst watersheds. J. Hydrol. 2017, 549, 428-451. [CrossRef]

97. Padovani, L.; Trevisan, M. I nitrati di origine agricola nelle acque sotterranee [Nitrates of agricultural origin in groundwater]. Quad. Tecnic. Prot. Ambient. 2002, 75, 120.

98. Palma, R.M.; Rímolo, M.; Saubidet, M.I.; Conti, M.E. Influence of tillage system on denitrification in maize-cropped soils. Biol. Fertil. Soils 1997, 25, 142-146. [CrossRef]

99. Wang, J.; Zou, J. No-till increases soil denitrification via its positive effects on the activity and abundance of the denitrifying community. Soil Biol. Biochem. 2020, 142, 107706. [CrossRef]

100. Capri, E.; Civita, M.; Corniello, A.; Cusimano, G.; De Maio, M.; Ducci, D.; Fait, G.; Fiorucci, A.; Hauser, S.; Pisciotta, A.; et al. Assessment of nitrate contamination risk: The Italian experience. J. Geochem. Explor. 2009, 102, 71-86. [CrossRef]

101. Rizeei, H.M.; Azeez, O.S.; Pradhan, B.; Khamees, H.H. Assessment of groundwater nitrate contamination hazard in a semi-arid region by using integrated parametric IPNOA and data-driven logistic regression models. Environ. Monit. Assess. 2018, 190, 633. [CrossRef]

102. Kazemi, E.; Karyab, H.; Emamjome, M.-M. Optimization of interpolation method for nitrate pollution in groundwater and assessing vulnerability with IPNOA and IPNOC method in Qazvin plain. J. Environ. Health Sci. Eng. 2017, 15, 23. [CrossRef] [PubMed] 
103. Ghiglieri, G.; Barbieri, G.; Vernier, A.; Carletti, A.; Demurtas, N.; Pinna, R.; Pittalis, D. Potential risks of nitrate pollution in aquifers from agricultural practices in the Nurra region, northwestern Sardinia, Italy. J. Hydrol. 2009, 379, 339-350. [CrossRef]

104. Pisciotta, A.; Cusimano, G.; Favara, R. Groundwater nitrate risk assessment using intrinsic vulnerability methods: A comparative study of environmental impact by intensive farming in the Mediterranean region of Sicily, Italy. J. Geochem. Explor. 2015, 156, 89-100. [CrossRef]

105. Watson, C.A.; Bengtsson, H.; Ebbesvik, M.; Løes, A.-K.; Myrbeck, A.; Salomon, E.; Schroder, J.; Stockdale, E.A. A review of farm-scale nutrient budgets for organic farms as a tool for management of soil fertility. Soil Use Manag. 2006, 18, 264-273. [CrossRef]

106. Gentry, L.E.; David, M.B.; Below, F.E.; Royer, T.V.; McIsaac, G.F. Nitrogen Mass Balance of a Tile-drained Agricultural Watershed in East-Central Illinois. J. Environ. Qual. 2009, 38, 1841-1847. [CrossRef] [PubMed]

107. Pinardi, M.; Soana, E.; Laini, A.; Bresciani, M.; Bartoli, M. Soil system budgets of N, Si and P in an agricultural irrigated watershed: Surplus, differential export and underlying mechanisms. Biogeochemistry 2018, 140, 175-197. [CrossRef]

108. Castaldelli, G.; Vincenzi, F.; Fano, E.A.; Soana, E. In Search for the Missing Nitrogen: Closing the Budget to Assess the Role of Denitrification in Agricultural Watersheds. Appl. Sci. 2020, 10, 2136. [CrossRef]

109. Cameira, M.R.; Rolim, J.; Valente, F.; Faro, A.; Dragosits, U.; Cordovil, C.M.d.S. Spatial distribution and uncertainties of nitrogen budgets for agriculture in the Tagus river basin in Portugal-Implications for effectiveness of mitigation measures. Land Use Policy 2019, 84, 278-293. [CrossRef]

110. Serra, J.; Cordovil, C.M.d.S.; Cruz, S.; Cameira, M.R.; Hutchings, N.J. Challenges and solutions in identifying agricultural pollution hotspots using gross nitrogen balances. Agric. Ecosyst. Environ. 2019, 283, 106568. [CrossRef]

111. Serra, J.; Cameira, M.d.R.; Cordovil, C.M.d.S.; Hutchings, N.J. Development of a groundwater contamination index based on the agricultural hazard and aquifer vulnerability: Application to Portugal. Sci. Total Environ. 2021, 772, 145032. [CrossRef] [PubMed]

112. He, W.; Jiang, R.; He, P.; Yang, J.; Zhou, W.; Ma, J.; Liu, Y. Estimating soil nitrogen balance at regional scale in China's croplands from 1984 to 2014. Agric. Syst. 2018, 167, 125-135. [CrossRef]

113. Leip, A.; Britz, W.; Weiss, F.; de Vries, W. Farm, land, and soil nitrogen budgets for agriculture in Europe calculated with CAPRI. Environ. Pollut. 2011, 159, 3243-3253. [CrossRef]

114. Rebolledo, B.; Gil, A.; Flotats, X.; Sánchez, J.Á. Assessment of groundwater vulnerability to nitrates from agricultural sources using a GIS-compatible logic multicriteria model. J. Environ. Manag. 2016, 171, 70-80. [CrossRef] [PubMed]

115. Arauzo, M.; García, G.; Valladolid, M. Assessment of the risks of N-loss to groundwater from data on N-balance surplus in Spanish crops: An empirical basis to identify Nitrate Vulnerable Zones. Sci. Total Environ. 2019, 696, 133713. [CrossRef] [PubMed]

116. Cameira, M.d.R.; Rolim, J.; Valente, F.; Mesquita, M.; Dragosits, U.; Cordovil, C.M.d.S. Translating the agricultural N surplus hazard into groundwater pollution risk: Implications for effectiveness of mitigation measures in nitrate vulnerable zones. Agric. Ecosyst. Environ. 2021, 306, 107204. [CrossRef]

117. Busico, G.; Mastrocicco, M.; Cuoco, E.; Sirna, M.; Tedesco, D. Protection from natural and anthropogenic sources: A new rating methodology to delineate "Nitrate Vulnerable Zones". Environ. Earth Sci. 2019, 78, 104. [CrossRef]

118. Bannenberg, M.; Ntona, M.M.; Busico, G.; Kalaitzidou, K.; Mitrakas, M.; Vargemezis, G.; Fikos, I.; Kazakis, N.; Voudouris, K. Hydrogeological and Hydrochemical Regime Evaluation in Flamouria Basin in Edessa (Northern Greece). Environments 2020, 7, 105. [CrossRef]

119. Morari, F.; Lugato, E.; Polese, R.; Berti, A.; Giardini, L. Nitrate concentrations in groundwater under contrasting agricultural management practices in the low plains of Italy. Agric. Ecosyst. Environ. 2012, 147, 47-56. [CrossRef]

120. Masetti, M.; Poli, S.; Sterlacchini, S. The Use of the Weights-of-Evidence Modeling Technique to Estimate the Vulnerability of Groundwater to Nitrate Contamination. Nat. Resour. Res. 2007, 16, 109-119. [CrossRef]

121. Tesoriero, A.J.; Voss, F.D. Predicting the Probability of Elevated Nitrate Concentrations in the Puget Sound Basin: Implications for Aquifer Susceptibility and Vulnerability. Ground Water 1997, 35, 1029-1039. [CrossRef]

122. Steichen, J.; Koelliker, J.; Grosh, D.; Heiman, A.; Yearout, R.; Robbins, V. Contamination of Farmstead Wells by Pesticides, Volatile Organics, and Inorganic Chemicals in Kansas. Groundw. Monit. Remediat. 1988, 8, 153-160. [CrossRef]

123. Chica-Olmo, M.; Luque-Espinar, J.A.; Rodriguez-Galiano, V.; Pardo-Igúzquiza, E.; Chica-Rivas, L. Categorical Indicator Kriging for assessing the risk of groundwater nitrate pollution: The case of Vega de Granada aquifer (SE Spain). Sci. Total Environ. 2014, 470-471, 229-239. [CrossRef] [PubMed]

124. Nolan, B.T.; Hitt, K.J. Vulnerability of Shallow Groundwater and Drinking-Water Wells to Nitrate in the United States. Environ. Sci. Technol. 2006, 40, 7834-7840. [CrossRef] [PubMed]

125. Nolan, B.T.; Gronberg, J.M.; Faunt, C.C.; Eberts, S.M.; Belitz, K. Modeling Nitrate at Domestic and Public-Supply Well Depths in the Central Valley, California. Environ. Sci. Technol. 2014, 48, 5643-5651. [CrossRef]

126. Gurdak, J.J.; Qi, S.L. Vulnerability of Recently Recharged Groundwater in Principle Aquifers of the United States To Nitrate Contamination. Environ. Sci. Technol. 2012, 46, 6004-6012. [CrossRef] [PubMed]

127. Sorichetta, A.; Ballabio, C.; Masetti, M.; Robinson, G.R.; Sterlacchini, S. A Comparison of Data-Driven Groundwater Vulnerability Assessment Methods. Groundwater 2013, 51, 866-879. [CrossRef]

128. Rodriguez-Galiano, V.; Mendes, M.P.; Garcia-Soldado, M.J.; Chica-Olmo, M.; Ribeiro, L. Predictive modeling of groundwater nitrate pollution using Random Forest and multisource variables related to intrinsic and specific vulnerability: A case study in an agricultural setting (Southern Spain). Sci. Total Environ. 2014, 476-477, 189-206. [CrossRef] 
129. Jang, C.-S.; Chen, S.-K. Integrating indicator-based geostatistical estimation and aquifer vulnerability of nitrate-N for establishing groundwater protection zones. J. Hydrol. 2015, 523, 441-451. [CrossRef]

130. Gurdak, J.J.; Geyer, G.E.; Nanus, L.; Taniguchi, M.; Corona, C.R. Scale dependence of controls on groundwater vulnerability in the water-energy-food nexus, California Coastal Basin aquifer system. J. Hydrol. Reg. Stud. 2017, 11, 126-138. [CrossRef]

131. Hagedorn, B.; Clarke, N.; Ruane, M.; Faulkner, K. Assessing aquifer vulnerability from lumped parameter modeling of modern water proportions in groundwater mixtures: Application to California's South Coast Range. Sci. Total Environ. 2018, 624, 1550-1560. [CrossRef] [PubMed]

132. Mair, A.; El-Kadi, A.I. Logistic regression modeling to assess groundwater vulnerability to contamination in Hawaii, USA. J. Contam. Hydrol. 2013, 153, 1-23. [CrossRef] [PubMed]

133. Boy-Roura, M.; Nolan, B.T.; Menció, A.; Mas-Pla, J. Regression model for aquifer vulnerability assessment of nitrate pollution in the Osona region (NE Spain). J. Hydrol. 2013, 505, 150-162. [CrossRef]

134. Leonard, R.A.; Knisel, W.G.; Still, D.A. GLEAMS: Groundwater Loading Effects of Agricultural Management Systems. Trans. ASAE 1987, 30, 1403-1418. [CrossRef]

135. Voss, C.I. A Finite Element Simulation Model for Saturated-Unsaturated Fluid Density-Dependent Groundwater Flow with Energy Transport or Chemically Reactive Single-Species Solute Transport; U.S. Geological Survey: Reston, VA, USA, 1984. [CrossRef]

136. Harbaugh, A.W. MODFLOW-2005, the US Geological Survey Modular Ground-Water Model-The Groundwater Flow Process; Book 6; U.S. Geological Survey: Reston, VA, USA, 2005.

137. Zheng, C.; Wang, P.P. MT3DMS: A Modular Three-Dimensional Multispecies Transport Model for Simulation of Advection, Dispersion, and Chemical Reactions of Contaminants in Groundwater Systems; Documentation and User's Guide; Contract Report SERDP-99-1; U.S. Army Engineer Research and Development Center: Vicksburg, MS, USA, 1999.

138. Diersch, H.J.G. FEFLOW: Finite Element Modeling of Flow, Mass and Heat Transport in Porous and Fractured Media; Springer: Berlin/Heidelberg, Germany, 2013. [CrossRef]

139. Appelo, C.A.J.; Rolle, M. PHT3D: A Reactive Multicomponent Transport Model for Saturated Porous Media. Ground Water 2010, 48, 627-632. [CrossRef]

140. Šimůnek, J.; Šejna, M.; van Genuchten, M.T. The HYDRUS-1D Software Package for Simulating the One-Dimensional Movement of Water, Heat, and Multiple Solutes in Variably-Saturated Media; University of California: Riverside, CA, USA, 2005; p. 240.

141. Šejna, M.; Šimůnek, J.; van Genuchten, M. The HYDRUS Software Package for Simulating Two-and Three-Dimensional Movement of Water, Heat, and Multiple Solutes in Variably-Saturated Media; User Manual, Version 3.01; PC-Progress: Prague, Czech Republic, 2018; p. 322.

142. Arnold, J.G.; Moriasi, D.N.; Gassman, P.W.; Abbaspour, K.C.; White, M.J.; Srinivasan, R.; Santhi, C.; Harmel, R.D.; van Griensven, A.; Van Liew, M.W.; et al. SWAT: Model Use, Calibration, and Validation. Trans. ASABE 2012, 55, 1491-1508. [CrossRef]

143. Prommer, H.; Barry, D.A.; Zheng, C. MODFLOW/MT3DMS-Based Reactive Multicomponent Transport Modeling. Ground Water 2003, 41, 247-257. [CrossRef]

144. Lim, J.-W.; Bae, G.-O.; Lee, K.-K. Groundwater vulnerability assessment by determining maximum contaminant loading limit in the vicinity of pumping wells. Geosci. J. 2009, 13, 79-85. [CrossRef]

145. Almasri, M.N.; Kaluarachchi, J.J. Modeling nitrate contamination of groundwater in agricultural watersheds. J. Hydrol. 2007, 343, 211-229. [CrossRef]

146. Conan, C.; Bouraoui, F.; Turpin, N.; de Marsily, G.; Bidoglio, G. Modeling Flow and Nitrate Fate at Catchment Scale in Brittany (France). J. Environ. Qual. 2003, 32, 2026-2032. [CrossRef]

147. Ameur, M.; Aouiti, S.; Hamzaoui-Azaza, F.; Cheikha, L.B.; Gueddari, M. Vulnerability assessment, transport modeling and simulation of nitrate in groundwater using SI method and modflow-MT3DMS software: Case of Sminja aquifer, Tunisia. Environ. Earth Sci. 2021, 80, 220. [CrossRef]

148. Uhan, J.; Vižintin, G.; Pezdič, J. Groundwater nitrate vulnerability assessment in alluvial aquifer using process-based models and weights-of-evidence method: Lower Savinja Valley case study (Slovenia). Environ. Earth Sci. 2011, 64, 97-105. [CrossRef]

149. Cui, C.; Zhou, W.; Geza, M. GIS-based nitrogen removal model for assessing Florida's surficial aquifer vulnerability. Environ. Earth Sci. 2016, 75, 526. [CrossRef]

150. Hansen, B.; Sonnenborg, T.O.; Møller, I.; Bernth, J.D.; Høyer, A.-S.; Rasmussen, P.; Sandersen, P.B.E.; Jørgensen, F. Nitrate vulnerability assessment of aquifers. Environ. Earth Sci. 2016, 75, 999. [CrossRef]

151. Huan, H.; Wang, J.; Lai, D.; Teng, Y.; Zhai, Y. Assessment of well vulnerability for groundwater source protection based on a solute transport model: A case study from Jilin City, northeast China. Hydrogeol. J. 2015, 23, 581-596. [CrossRef]

152. Huan, H.; Wang, J.; Zhai, Y.; Xi, B.; Li, J.; Li, M. Quantitative evaluation of specific vulnerability to nitrate for groundwater resource protection based on process-based simulation model. Sci. Total Environ. 2016, 550, 768-784. [CrossRef] [PubMed]

153. Huan, H.; Hu, L.; Yang, Y.; Jia, Y.; Lian, X.; Ma, X.; Jiang, Y.; Xi, B. Groundwater nitrate pollution risk assessment of the groundwater source field based on the integrated numerical simulations in the unsaturated zone and saturated aquifer. Environ. Int. 2020, 137, 105532. [CrossRef] [PubMed]

154. Aschonitis, V.G.; Salemi, E.; Colombani, N.; Castaldelli, G.; Mastrocicco, M. Formulation of Indices to Describe Intrinsic Nitrogen Transformation Rates for the Implementation of Best Management Practices in Agricultural Lands. Water Air Soil Pollut. 2013, 224, 1489. [CrossRef] 
155. Aschonitis, V.G.; Mastrocicco, M.; Colombani, N.; Salemi, E.; Kazakis, N.; Voudouris, K.; Castaldelli, G. Assessment of the Intrinsic Vulnerability of Agricultural Land to Water and Nitrogen Losses via Deterministic Approach and Regression Analysis. Water Air Soil Pollut. 2012, 223, 1605-1614. [CrossRef]

156. Kazakis, N.; Voudouris, K.S. Groundwater vulnerability and pollution risk assessment of porous aquifers to nitrate: Modifying the DRASTIC method using quantitative parameters. J. Hydrol. 2015, 525, 13-25. [CrossRef]

157. Huan, H.; Wang, J.; Teng, Y. Assessment and validation of groundwater vulnerability to nitrate based on a modified DRASTIC model: A case study in Jilin City of northeast China. Sci. Total Environ. 2012, 440, 14-23. [CrossRef]

158. Busico, G.; Kazakis, N.; Colombani, N.; Mastrocicco, M.; Voudouris, K.; Tedesco, D. A modified SINTACS method for groundwater vulnerability and pollution risk assessment in highly anthropized regions based on $\mathrm{NO}_{3}{ }^{-}$and $\mathrm{SO}_{4}{ }^{2-}$ concentrations. Sci. Total Environ. 2017, 609, 1512-1523. [CrossRef]

159. Busico, G.; Kazakis, N.; Cuoco, E.; Colombani, N.; Tedesco, D.; Voudouris, K.; Mastrocicco, M. A novel hybrid method of specific vulnerability to anthropogenic pollution using multivariate statistical and regression analyses. Water Res. 2020, $171,115386$. [CrossRef] [PubMed]

160. Jia, Z.; Bian, J.; Wang, Y.; Wan, H.; Sun, X.; Li, Q. Assessment and validation of groundwater vulnerability to nitrate in porous aquifers based on a DRASTIC method modified by projection pursuit dynamic clustering model. J. Contam. Hydrol. 2019, 226, 103522. [CrossRef] [PubMed]

161. Zhang, Y.; Zhang, S.; Liu, C.L.; Hou, H.B.; Dong, H.; Zhang, M. Prospect of capability of aeration zone in soil in prevention nitrogen from pollution of groundwater. J. Agro-Environ. Sci. 2006, 25, 339-346.

162. Leifeld, J.; Kögel-Knabner, I. Soil organic matter fractions as early indicators for carbon stock changes under different land-use? Geoderma 2005, 124, 143-155. [CrossRef]

163. Voutchkova, D.D.; Schullehner, J.; Rasmussen, P.; Hansen, B. A high-resolution nitrate vulnerability assessment of sandy aquifers (DRASTIC-N). J. Environ. Manag. 2021, 277, 111330. [CrossRef]

164. Juncher Jørgensen, C.; Jacobsen, O.S.; Elberling, B.; Aamand, J. Microbial Oxidation of Pyrite Coupled to Nitrate Reduction in Anoxic Groundwater Sediment. Environ. Sci. Technol. 2009, 43, 4851-4857. [CrossRef]

165. Bigi, V.; Pezzoli, A.; Comino, E.; Rosso, M. A Vulnerability Assessment in Scant Data Context: The Case of North Horr Sub-County. Sustainability 2020, 12, 6024. [CrossRef]

166. Field, C.B.; Barros, V.R.; Dokken, D.J.; Mach, K.J.; Mastrandrea, M.D.; Bilir, T.E.; Chatterjee, M.; Yuka, K.L.E.; Estrada, O.; Genova, R.C.; et al. Climate Change 2014 Impacts, Adaptation, and Vulnerability Part A: Global and Sectoral Aspects Working Group II Contribution to the Fifth Assessment Report of the Intergovernmental Panel on Climate Change; Cambridge University Press: New York, NY, USA, 2014; ISBN 978-1-107-05807-1.

167. Cardona, O.-D.; van Aalst, M.K.; Birkmann, J.; Fordham, M.; McGregor, G.; Perez, R.; Pulwarty, R.S.; Lisa Schipper, E.F.; Tan Sinh, B.; Décamps, H.; et al. Determinants of risk: Exposure and vulnerability. In Managing the Risks of Extreme Events and Disasters to Advance Climate Change Adaptation; Cambridge University Press: Cambridge, UK; New York, NY, USA, 2012.

168. U.S. Environmental Protection Agency. Risk Assessment Guidance for Superfund. Volume 1: Human Health Evaluation Manual; U.S. EPA: Washington, DC, USA, 1989.

169. Hancock, P.J.; Boulton, A.J.; Humphreys, W.F. Aquifers and hyporheic zones: Towards an ecological understanding of groundwater. Hydrogeol. J. 2005, 13, 98-111. [CrossRef]

170. Erostate, M.; Huneau, F.; Garel, E.; Ghiotti, S.; Vystavna, Y.; Garrido, M.; Pasqualini, V. Groundwater dependent ecosystems in coastal Mediterranean regions: Characterization, challenges and management for their protection. Water Res. 2020, $172,115461$. [CrossRef] [PubMed] 